MEDIA ILMIAH TEKNIK SIPIL

\title{
ANALISIS KONSTRUKSI BANGUNAN BERTINGKAT TERHADAP BEBAN GEMPA SNI-03-1726-2019 DENGAN INFILLED FRAME
}

\author{
CONSTRUCTION ANALYSIS OF BUILDING AGAINST EARTHQUAKE LOAD \\ SNI-03-1726-2019 WITH INFILLED FRAME
}

\author{
Maya Saridewi Pascanawaty ${ }^{* 1}$, Agustini Ernawati $^{2}$, Titik Wahyuningsih ${ }^{3}$ \\ ${ }^{1,2,3}$ Teknik Sipil Fakultas Teknik, Universitas Muhammadiyah Mataram \\ Korespondensi: mayasardepa@gmail.com
}

\begin{abstract}
ABSTRAK
Batu bata merah merupakan salah satu material yang masih cukup banyak digunakan dalam praktek konstruksi, karena cukup mudah mendapatkannya dan harganya relatif murah. Dinding pasangan bata merah merupakan pasangan yang terdiri dari bahan pengikat (mortar) dan bahan pengisi (bata merah) dikenal dengan nama masonry. Masonry umumnya memberikan konstruksi yang tahan lama, dimana bahan pembentuknya, kualitas mortar, dan cara pengerjaan sangat mempengaruhi ketahanan konstruksi dinding secara keseluruhan. Pemasangan dinding pengisi mengakibatkan struktur menjadi lebih kaku, yang terkadang dapat menyebabkan terjadinya perilaku keruntuhan yang berbeda antara struktur tanpa dinding pengisi dan struktur dengan dinding pengisi. Hal yang demikian mempengaruhi juga kapasitas dan daktilitas struktur secara keseluruhan. Beberapa hasil penelitian menunjukkan bahwa interaksi dinding pengisi dengan kerangka sangat efektif meningkatkan kekuatan, kekakuan, dan kinerja struktur dalam menahan beban lateral akibat gempa. Penelitian ini mengambil contoh gedung 4 (empat) lantai. Analisa dilakukan dengan memodel dinding pada aplikasi software SAP2000, dimana model struktur tersebut antara lain: Model I sepenuhnya menggunakan frame element, Model II merupakan struktur yang dimodel dengan mengikut sertakan dinding pengisi tanpa plesteran sebagai shell element, Model III merupakan struktur yang dimodel menggunakan dinding pengisi dengan perkuatan plesteran sebagai shell element, dan Model IV merupakan struktur yang dimodel menggunakan dinding pengisi dengan perkuatan plesteran dan kawat loket sebagai shell element. Parameter pembanding dalam penelitian ini adalah kekuatan struktur dan deformasi. Berdasarkan hasil analisa, Model II, $90 \%$ lebih kaku dibandingkan dengan struktur rangka terbuka (open frame) Model I; sedangkan Model III, $92 \%$ lebih kaku dibandingkan dengan Model I; dan Model IV, 97 \% lebih kaku dibandingkan dengan Model I yang jika ditinjau dari akibat beban gempa arah X. Jika ditinjau dari akibat beban gempa arah $\mathrm{Y}$, rangka struktur dengan dinding pengisi (infilled frame) untuk Model II, $88 \%$ lebih kaku dibandingkan dengan struktur rangka terbuka (open frame) Model I; sedangkan Model III, $91 \%$ lebih kaku dibandingkan dengan Model I; dan Model IV, $99 \%$ lebih kaku dibandingkan dengan Model I. Nilai momen dan gaya lintang Model II, Model III, Model IV lebih kecil dibandingkan dengan Model I baik ditinjau akibat beban gempa arah X maupun akibat beban gempa arah Y. Tegangan yang terjadi pada dinding pengisi Model II lebih besar dibandingkan dengan Model IV dan Model III jika ditinjau akibat beban gempa arah X maupun ditinjau akibat beban gempa arah Y. Dari segi keamanan, struktur gedung bertingkat yang menggunakan dinding pengisi jauh lebih aman dan lebih kaku dibandingkan dengan struktur rangka terbuka dan sangat memenuhi syarat untuk digunakan pada daerah yang beresiko gempa tinggi.
\end{abstract}

Kata Kunci: masonry, infilled frame, kekakuan

Media Ilmiah Teknik Sipil, Volume 10, Nomor 1, Desember 2021: 30-40 
Analisis Konstruksi .., Maya Saridewi Pascanawaty ${ }^{(1)}$, Agustini Ernawati ${ }^{(2)}$ Titik Wahyuningsih $^{(3)}$

\section{ABSTRACT}

Red brick is one of the materials that is still quite widely used in construction practice, because it is quite easy to get and the price is relatively cheap. Red masonry wall is a pair consisting of a binder (mortar) and a filler (red brick) known as masonry. Masonry generally provides durable construction, where the constituent material, mortar quality, and workmanship greatly affect the durability of the overall wall construction. The installation of infill walls causes the structure to become more rigid, which can sometimes cause different failure behavior between structures without infill walls and structures with infill walls. This also affects the capacity and ductility of the overall structure. Several research results show that the interaction of the infill wall with the framework is very effective in increasing the strength, stiffness, and performance of the structure in resisting lateral loads due to earthquakes. This study takes the example of a 4 (four) floor building. The analysis is carried out by modeling the walls in the SAP2000 software application, where the structural models include: Model I fully uses frame elements, Model II is a structure modeled by including infill walls without plastering as a shell element, Model III is a structure modeled using infill walls with stucco reinforcement as the shell element, and Model IV is a structure modeled using infill walls with stucco reinforcement and counter wire as the shell element. The comparison parameters in this study are structural strength and deformation. Based on the results of the analysis, Model II, 90\% stiffer than the open frame structure (open frame) Model I; while Model III is 92\% stiffer than Model I; and Model IV, 97\% stiffer than Model I which, when viewed from the X-direction earthquake load. When viewed from the Y-direction earthquake load, the infilled frame structure for Model II is $88 \%$ stiffer than the open frame structure (open frame) Model I; while Model III is 91\% stiffer than Model I; and Model IV, 99 \% stiffer than Model I. Moment and latitude values of Model II, Model III, Model IV are smaller than Model I both in terms of the X-direction earthquake load and the Y-direction earthquake load. Infill walls of Model II are larger than those of Model $I V$ and Model III when viewed from the X-direction earthquake load or due to the Y-direction earthquake load. and very qualified for use in areas with high earthquake risk.

Keywords: masonry, infilled frame, stiffness

\section{PENDAHULUAN}

Batu bata merah merupakan salah satu material yang masih cukup banyak digunakan dalam praktek konstruksi, karena cukup mudah mendapatkannya dan harganya relatif murah. Dinding pasangan bata merah merupakan pasangan yang terdiri dari bahan pengikat (mortar) dan bahan pengisi (bata merah) juga dikenal dengan nama masonry. Masonry umumnya memberikan konstruksi yang tahan lama, dimana bahan pembentuknya dan cara pengerjaan sangat mempengaruhi ketahanan konstruksi dinding secara keseluruhan. Sumbangan dinding pengisi dalam meningkatkan kekakuan dan kekuatan struktur bangunan tidak selamanya menguntungkan. Ada kalanya penempatan dinding pada bangunan tidak beraturan sehingga dapat menimbulkan ketimpangan kekakuan antar lantai yang mencolok. Kondisi ini sering dijumpai pada bangunan-bangunan umum seperti hotel, perkantoran, rumah susun dan bangunan lain dengan ruang terbuka pada tingkat bawah bangunan. Jika rasio kekakuan tingkat ke-i kurang dari $70 \%$ dari kekakuan tingkat ke-i+1
(SNI-03-1726-2019) maka struktur dinyatakan potensial mengalami kegagalan tingkat lunak. Pemasangan dinding pengisi mengakibatkan struktur menjadi lebih kaku, yang terkadang dapat menyebabkan terjadinya perilaku keruntuhan yang berbeda antara struktur tanpa dinding pengisi dan struktur dengan dinding pengisi. Hal yang demikian mempengaruhi juga kapasitas dan daktilitas struktur secara keseluruhan. Dinding pengisi juga berfungsi sebagai struktur yang sudah terbukti kuat dan handal sejak beberapa dekade terakhir. Pada bangunan dengan bentangan lebih besar dan bertingkat, lebih banyak digunakan kerangka beton bertulang atau kerangka baja sebagai struktur utama, sedangkan dinding pemisah ruang yang ada di antara kolom struktur dianggap bukan bagian dari struktur. Pada bangunan dengan bentangan lebih besar dan bertingkat, lebih banyak digunakan kerangka beton bertulang atau kerangka baja sebagai struktur utama, sedangkan dinding pemisah ruang yang ada di antara kolom struktur dianggap bukan bagian dari struktur. Hotel, apartemen dan rumah susun bertingkat merupakan contoh struktur bangunan kerangka dengan dinding pengisi yang banyak 
dibuat di Indonesia dan negara-negara lain. Kadang kala struktur portal terbuka yang direncanakan dapat berperilaku sebagai portal daktail saat gempa, akibat adanya dinding pengisi yang tidak merata dapat berubah menjadi struktur yang mempunyai mekanisme keruntuhan soft-story yang berbahaya. Maka dengan meninjau hal tersebut diperlukan perkuatan struktur rangka dengan penambahan dinding pengisi (infilled frame). Berdasarkan latar belakang tersebut maka perlu dilakukan penelitian mengenai karakteristik dinding pasangan bata dan material pembentuknya. Dalam penelitian ini dilakukan penelitian kekuatan dinding menggunakan pasangan bata tanpa plesteran, dengan perkuatan plesteran, dan dengan perkuatan kawat terhadap beban gempa yang menggunakan Standar Nasional Indonesia (SNI) terbaru yaitu SNI 03-1726-2019.

Tujuan yang ingin dicapai adalah untuk mengetahui apakah struktur rangka dengan penambahan dinding pengisi (infilled frame) dengan menggunakan pasangan bata tanpa plesteran, dengan perkuatan plesteran, dan dengan perkuatan kawat mampu memperkuat struktur dan bagaimanakah kondisi struktur tersebut sebelum dan sesudah diperkuat dengan dinding pengisi ketika menerima beban lateral (beban gempa) SNI 03-1726-2019. Parameter pembanding dalam penelitian ini adalah kekuatan struktur, deformasi dan daktilitas struktur.

Untuk mencapai tujuan dari penelitian ini maka dilakukan pembatasan sebagai berikut: (1) Dimensi struktur yang direncanakan sudah memenuhi syarat berdasarkan ketentuan Tata Cara Perencanaan Struktur Beton Untuk Bangunan Gedung SNI-03-2847-2019 dengan analisis struktur metode linier dan analisa terhadap beban gempa berdasarkan ketentuan Tata Cara Perencanaan Ketahanan Gempa Untuk Struktur Bangunan Gedung SNI-03-1726-2019; (2) Pemodelan infilled frame adalah terhadap struktur gedung 4 (empat) lantai; (3) Analisa dilakukan dengan memodel dinding pada aplikasi software SAP2000, dimana model struktur tersebut antara lain yaitu Model I sepenuhnya menggunakan frame element. Model II merupakan struktur yang dimodel dengan mengikut sertakan dinding pengisi tanpa plesteran sebagai shell element. Model III merupakan struktur yang dimodel menggunakan dinding pengisi dengan perkuatan plesteran sebagai shell element. Model IV merupakan struktur yang dimodel menggunakan dinding pengisi dengan perkuatan plesteran dan kawat loket sebagai shell element; dan (4) Portal yang ditinjau adalah portal yang mengalami deformasi paling besar akibat beban gempa¥

\section{TINJAUAN PUSTAKA}

\section{Metode Analisa Struktur}

Menurut Analysis Reference SAP2000, metode analisa menjelaskan bagaimana beban dikerjakan pada struktur (statis dan dinamis) dan bagaimana respon struktur (linier ataupun nonlinier). Terdapat banyak perbedaan tipe analisa, namun kebanyakan analisa digolongkan menjadi 2 (dua) yaitu analisa linier dan analisa nonlinier. Struktur digolongkan ke dalam analisa linier jika: (1) karakteristik struktur (kekakuan, redaman, dan sebagainya) konstan selama analisa; (2) analisa mulai dengan kondisi tegangan awal nol yang tidak mengikutsertakan beban dari analisa sebelumnya, walaupun menggunakan kekakuan dari analisa nonlinier sebelumnya; dan (3) seluruh hasil analisa berupa lendutan, gaya dalam, reaksi, dan sebagainya sebanding dengan beban yang bekerja, serta hasil analisa linier yang berbeda dapat langsung disuperposisikan setelah semua analisa berakhir. Sedangkan struktur digolongkan ke dalam analisa nonlinier jika karakteristik struktur dapat berubah-ubah terhadap waktu, deformasi, dan karakteristik struktur yang bervariasi dengan respon struktur yang mungkin saja tidak berbanding linier dengan pembebanan. Analisa statis nonlinier dapat digunakan untuk beberapa tujuan meliputi: analisa struktur berdasarkan kenonlinieran material dan kenonlinieran geometri, analisa statik pushover, analisa konstruksi bertahap, dan analisa kabel.

\section{Peran Dinding Pengisi}

Dinding adalah bagian dari bangunan yang berfungsi sebagai pemisah antara ruangan luar dengan ruangan dalam, melindungi terhadap cuaca, penyokong atap, sebagai pembatas, penahan cahaya panas dari matahari, menahan tiupan angin dari luar. Dinding adalah bagian bangunan yang sangat penting perannya bagi suatu konstruksi bangunan. Dinding membentuk dan melindungi isi bangunan baik dari segi konstruksi maupun penampilan artistik dari bangunan (Fianli, 2011). Menurut Fianli (2011), fungsi dinding dalam konstruksi adalah sebagai pemikul yang harus kuat dan kokoh agar mampu menahan bebannya sendiri dan beban horizontal, dan dinding berfungsi sebagai pembatas/partisi, tidak perlu kokoh tetapi 
harus kaku sehingga perlu kolom penguat.

Sumbangan dinding pengisi dalam meningkatkan kekakuan dan kekuatan struktur bangunan tidak selamanya menguntungkan. Ada kalanya penempatan dinding pada bangunan tidak beraturan sehingga dapat menimbulkan ketimpangan kekakuan antar lantai yang mencolok. Kondisi ini sering dijumpai pada bangunan-bangunan umum seperti hotel, perkantoran, rumah susun dan bangunan lain dengan ruang terbuka pada tingkat bawah bangunan. Jika rasio kekakuan tingkat ke-i kurang dari $70 \%$ dari kekakuan tingkat ke-i+1 (SNI-03-1726-2019) maka struktur dinyatakan potensial mengalami kegagalan tingkat lunak.

Gambar 1 menunjukkan potensi tingkat lunak akibat penempatan dinding tidak beraturan seperti efek kolom pendek, tingkat lunak pada lantai dasar dan tingkat lunak pada lantai atas. Dalam praktek konstruksi bangunan, hanya balok dan kolom yang digambar sebagai komponen struktur sementara dinding pengisi tidak, sehingga potensi tingkat lunak tidak terlihat. Lebih buruk lagi, dinding pengisi ini tidak diperhitungkan dalam analisis sehingga konsultan perencana struktur tidak melihat potensi bahaya (Sukrawa, 2020).

Pada kejadian gempa Kobe tahun 1995, sekitar 55.000 bangunan hancur dan sebagian besar disebabkan oleh tingkat lunak terutama lantai dasar lebih lemah dibandingkan tingkat diatasnya, sehingga mengalami kegagalan tingkat lunak/soft story failure. Gambar 2.2 menunjukkan contoh kegagalan tingkat lunak dalam Gempa Kobe. Contoh lain kegagalan tingkat lunak disajikan dalam Gambar 2 Gempa Lombok pada 5 Agustus tahun 2018 dengan magnitude 7,0 menghancurkan sebagian pemukiman dengan 560 korban jiwa dan kerugian materi lebih dari 5 triliun rupiah (BNPB, 2018). Gambar 2.4 menunjukkan contoh kerusakan bangunan bertingkat di Kabupaten Lombok Utara.

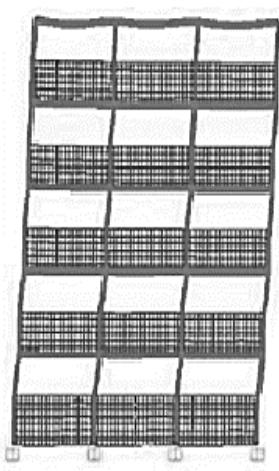

(a)

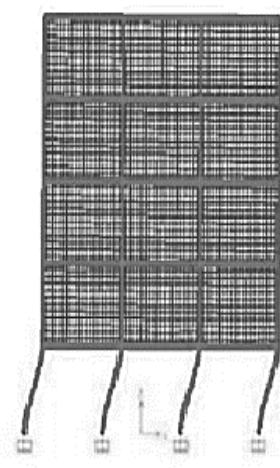

(b)

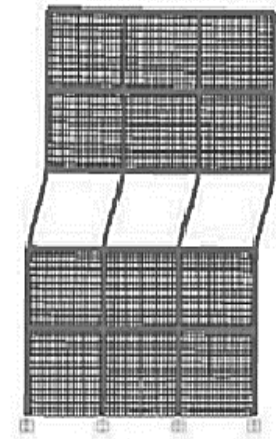

(c)

Gambar 1. Kolom Pendek (a), Lantai Dasar Lunak (b) dan Lantai Atas Lunak (c)

(Sumber: Sukrawa, 2020)

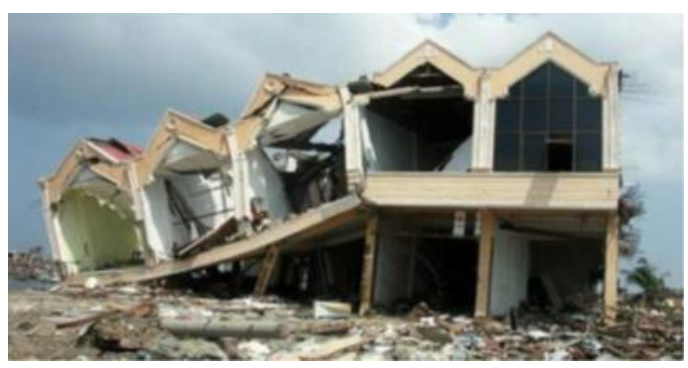

Gambar 2. Kerusakan Bangunan Akibat Gempa Lombok Tahun 2018

(Sumber: https://indopos.co.id/read/2018/08/11/146928/samijo-banten-aksi-peduli-gempa-lombok/)

\section{Bahan Pembentuk Dinding Pasangan}

Menurut SNI 15-0686-1989, beberapa klasifikasi bata merah menurut kekuatannya dibagi dalam 5 (lima) kelas. Berdasarkan nilai rata-rata kuat tekan bruto terendah, diantaranya: kelas 50 , 100, 150, 200, dan 250. Batu bata kelas 50, 100, 150 , 200, dan 250 masing-masing memiliki kuat tekan sebesar $5 \mathrm{~N} / \mathrm{mm}^{2}, 10 \mathrm{~N} / \mathrm{mm}^{2}, 15 \mathrm{~N} / \mathrm{mm}^{2}, 20$ 
$\mathrm{N} / \mathrm{mm}^{2}$, dan $25 \mathrm{~N} / \mathrm{mm}^{2}$.

Mortar adalah campuran yang terdiri dari semen, agregat halus, dan air baik dalam keadaan dikeraskan ataupun tidak dikeraskan (SNI 15-2049-2004). Campuran mortar konvensional untuk dinding bata misalnya $1: 5$, artinya 1 takaran semen : 5 takaran pasir. Tebal mortar yang menyatukan bata berkisar antara $0,65-2 \mathrm{~cm}$.

Dalam BS 5628-1-1992, disebutkan ada 4 jenis campuran mortar (semen: pasir), yaitu: 1:3 (i), 1:4 (ii), 1:5 (iii), 1:6 (iv) yang masing-masing memiliki kuat tekan minimum $16 \mathrm{~N} / \mathrm{mm}^{2}, 6,5$ $\mathrm{N} / \mathrm{mm}^{2}, 3,6 \mathrm{~N} / \mathrm{mm}^{2}, 1,5 \mathrm{~N} / \mathrm{mm}^{2}$ (Tabel 1).

Tabel 1. Klasifikasi mortar

\begin{tabular}{|c|c|c|c|c|c|}
\hline \multirow{2}{*}{$\begin{array}{l}\text { Mortar } \\
\text { designa- } \\
\text { tion }\end{array}$} & \multicolumn{3}{|c|}{ Types of mortar (proportion by volume) } & \multicolumn{2}{|c|}{$\begin{array}{c}\text { Mean Compressive Strength at } \\
28 \text { days }\left(\mathrm{N} / \mathrm{mm}^{2}\right)\end{array}$} \\
\hline & $\begin{array}{l}\text { Cement: Lime: } \\
\text { Sand }\end{array}$ & $\begin{array}{c}\text { Masonry } \\
\text { Cement: Sand }\end{array}$ & $\begin{array}{c}\text { Cement:Sand } \\
\text { with plasticizer }\end{array}$ & $\begin{array}{c}\text { Preliminary } \\
\text { (Laboratory tests) }\end{array}$ & Site Test \\
\hline (i) & $1: 0$ to $1 / 4: 3$ & - & $1: 3$ & 16.0 & 11.0 \\
\hline (ii) & $1: 1 / 2: 4$ to $41 / 2$ & $1: 21 / 2$ to $31 / 2$ & $1: 3$ to 4 & 6.5 & 4.5 \\
\hline (iii) & $1: 1: 5$ to6 & $1: 4$ to5 & $1: 5$ to 6 & 3.6 & 2.5 \\
\hline (iv) & $1: 2: 8$ to 9 & $1: 51 / 2$ to61/2 & $1: 7$ to8 & 1.5 & 1.0 \\
\hline
\end{tabular}

Menurut SNI-07-0663-1995, jaringan kawat baja las untuk tulangan adalah jaringan yang berbentuk segi empat dari kawat hasil penarikan dingin yang dibuat dengan pengelasan titik, dimana dapat berbentuk bujur sangkar dan jaring empat persegi panjang. Sebelum digunakan sebagai perkuatan pada dinding pasangan harus memperhatikan beberapa hal berikut, yaitu kawat-kawat satu sama lain harus saling tegak lurus dan tidak boleh terdapat cacat-cacat yang dapat mengurangi kegunaannya. Panjang juntaian kawat adalah maksimum $1 / 2 \quad \mathrm{x}$ jarak kawat melintang. dan untuk pengujian jaringan kawat baja yaitu dengan mengambil satu benda uji sebanyak 2 (dua) lembar yang berukuran 1 x 1 meter dari per tiap 10 (sepuluh) bundel. Pengukuran diameter dilakukan terhadap kawat baja yang melintang dan memanjang, masing-masing pada dua titik pengukuran. Ukuran jaring ditentukan dengan mengukur secara acak lebar maupun panjang jaring minimum 3 kali pengukuran

\section{METODE}

Analisa dilakukan dengan memodel dinding pada software aplikasi SAP2000, dimana model struktur tersebut antara lain: Model I sepenuhnya menggunakan elemen frame (Gambar 3, Gambar 5 dan Gambar 6). Model II merupakan struktur yang dimodel dengan mengikut sertakan dinding pengisi tanpa plesteran sebagai shell element pada pemodelannya (Gambar 7 dan Gambar 8). Model
III merupakan struktur yang dimodel menggunakan dinding pengisi dengan perkuatan plesteran sebagai shell element pada pemodelannya (Gambar 7 dan Gambar 9). Model IV merupakan struktur yang dimodel menggunakan dinding pengisi dengan perkuatan plesteran dan kawat loket sebagai shell element pada pemodelannya (Gambar 7 dan Gambar 10). Penempatan/pemodelan dinding pengisi (infilled frame) yaitu pada lantai dasar (lantai I) dapat dilihat di Gambar 7. Parameter pembanding dalam penelitian ini adalah kekuatan struktur, deformasi dan daktilitas struktur dari 4 (empat) model tersebut. Instrumen dari penelitian ini adalah program SAP 2000 V.16 dimana beberapa penelitian sebelumnya juga menggunakan program ini dan dianggap sebagai program yang relevan dalam pemodelan infilled frame. Adapun denah, tampak dari bangunan dan rencana penempatan dinding pengisi dalam penelitian ini dapat dilihat pada gambar 1 - gambar 8 .

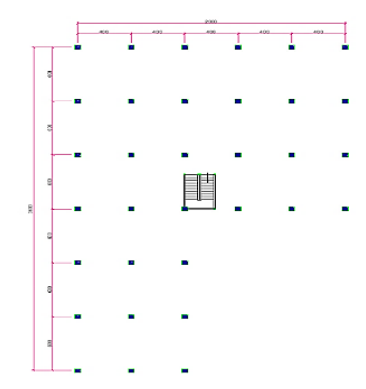

Gambar 3. Lantai 1 (area parkir kendaraan) 

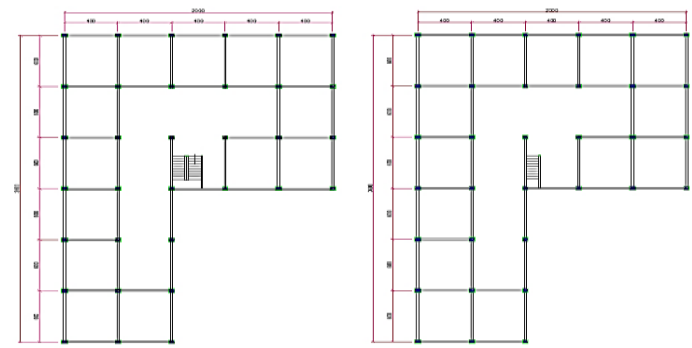

(a)

(b)

Gambar 4. Lantai 2, Lantai 3 (a) dan Lantai 4 (b)

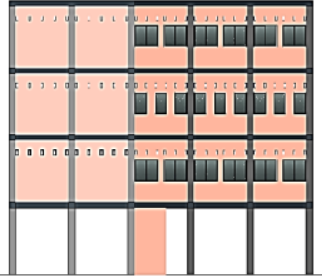

(a)

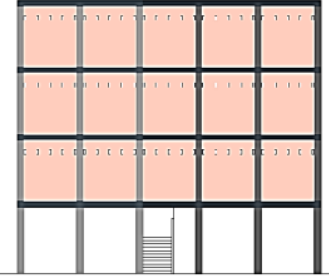

(b)
Gambar 5. Tampak Depan (a) dan Tampak Belakang (b)
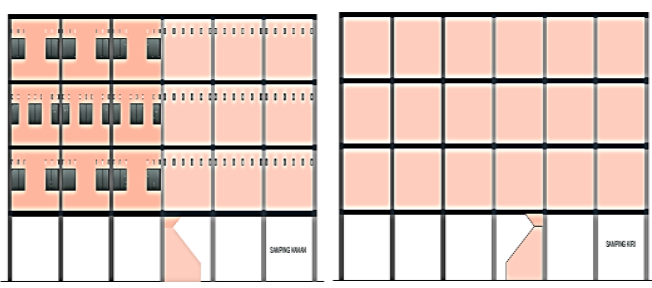

Gambar 6. Tampak Samping

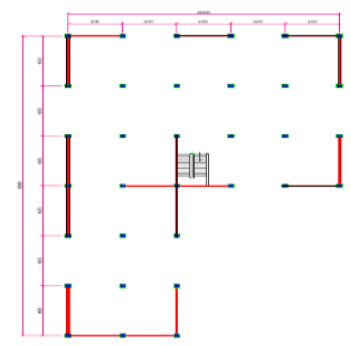

Gambar 7. Penempatan dinding pengisi/infilled frame (garis warna merah)
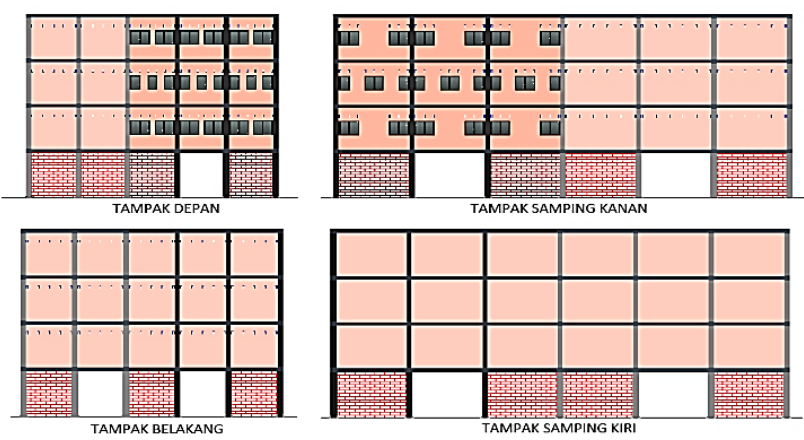

Gambar 8. Infilled frame pada lantai I, pasangan bata tanpa plesteran (Model II)
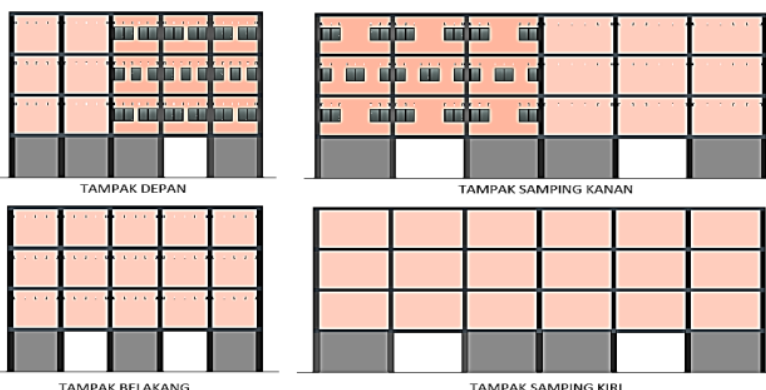

Gambar 9. Infilled frame pada lantai I, pasangan bata dengan plesteran (Model II)
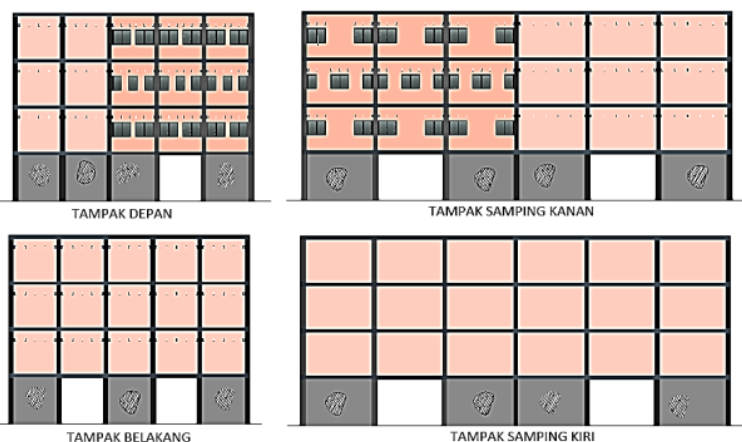

Gambar 10 Infilled frame pada lantai I, pasangan bata dengan perkuatan plesteran dan kawat loket (Model IV)

Untuk membandingkan hasil analisis dan pemodelan pada struktur dengan dan tanpa dinding pengisi dengan bantuan software SAP2000 V.16, dimensi balok dan kolom diambil dari perolehan data yang ada di lapangan. Sesuai batasan lingkup penelitian, dimensi struktur yang direncanakan sudah memenuhi syarat berdasarkan ketentuan Tata Cara Perencanaan Struktur Beton Untuk Bangunan Gedung SNI-03-2847-2019 dengan analisis struktur metode linier dan analisa terhadap beban gempa berdasarkan ketentuan Tata Cara Perencanaan Ketahanan Gempa Untuk Struktur Bangunan Gedung SNI-03-1726-2019. Pada aplikasi SAP2000, langkah awal yang dilakukan adalah menggambar model struktur secara keseluruhan dan mendefinisikan sifat material yang digunakan yaitu antara lain untuk open frame dengan $f^{\prime} c 28 \mathrm{MPa}$, fyl $300 \mathrm{Mpa}$, fys 240 $\mathrm{MPa}$, tinggi kolom $4000 \mathrm{~mm}$, dimensi balok lantai $300 / 400(\mathrm{~mm} / \mathrm{mm})$, dimensi balok atap 200/300 $(\mathrm{mm} / \mathrm{mm})$, dan dimensi kolom 500/500 $(\mathrm{mm} / \mathrm{mm})$. Dinding pengisi dengan $f^{\prime} c$ bata $11 \mathrm{MPa}, f^{\prime} c$ mortar $9 \mathrm{MPa}$, diameter kawat loket $1 \mathrm{~mm}$-spasi 20 $\mathrm{mm}$. Ketebalan dinding pengisi, $100 \mathrm{~mm}$ untuk dinding tanpa plesteran, $150 \mathrm{~mm}$ untuk dinding dengan plesteran dan $150 \mathrm{~mm}$ untuk dinding dengan perkuatan plesteran dan kawat 
loket (Gambar 11). Sedangkan langkah-langkah analisis dalam penelitian ini dapat dilihat pada gambar 10
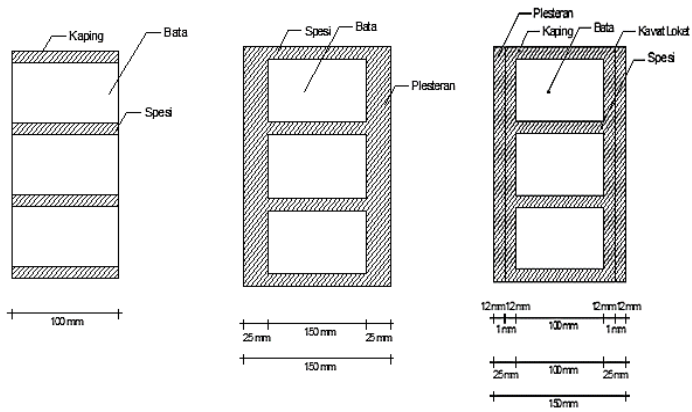

Gambar 11. Tebal dinding tanpa plesteran (a), dinding dengan plesteran (b), dan dinding plesteran dengan perkuatan kawat loket (c)

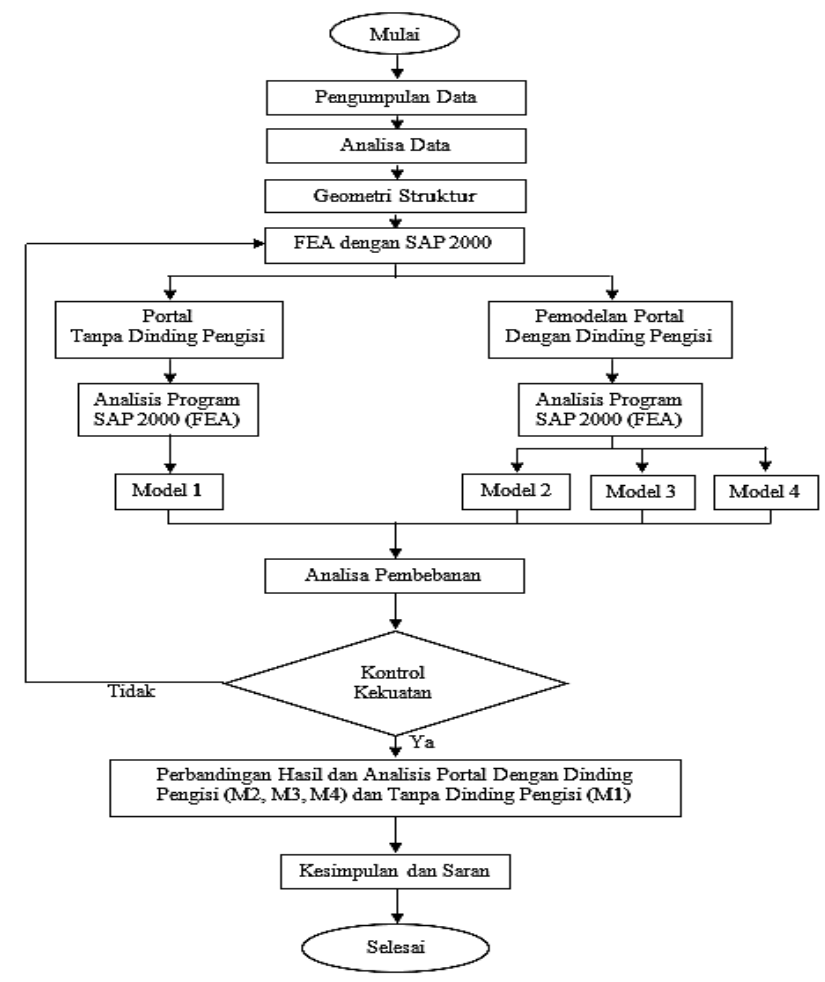

Gambar 12. Bagan Rancangan Penelitian

\section{HASIL DAN PEMBAHASAN}

\section{Hasil Analisa Pembebanan Gempa}

Analisis struktur terhadap pembebanan gempa pada gedung dilakukan dengan analisis metode statik ekivalen dengan kondisi struktur tanah sedang mengacu pada SNI 03-1726-2019. Berdasarkan peta zona wilayah gempa dibagi menurut percepatan respon spektra yaitu percepatan respon spektra periode pendek (percepatan respon spektra 0,2 detik di batuan dasar) dengan faktor redaman 5\%, dalam penelitian ini Kota Mataram memiliki percepatan respon spektra $1,0 \mathrm{~g}$ dan percepatan respon spektra periode 1 detik di batuan dasar dengan probabilitas 2\% serta faktor redaman 5\% Kota Mataram memiliki percepatan respon spektra $0,4 \mathrm{~g}$. Faktor keutamaan gedung berdasarkan (Tabel 3 dan Tabel 4) dalam peraturan SNI 03-1726-2019 untuk gedung perkantoran dengan faktor resiko II diperoleh faktor keutamaan (I) $=1,00$ dengan kondisi struktur tanah sedang (SD), dimana $\mathrm{Fa}$ atau Fv ditentukan dengan menggunakan masing-masing koefisien situs sesuai (Tabel 6 dan Tabel 7) dalam peraturan SNI 03-1726-2019, dan didapat nilai $\mathrm{Fa}=1.10$ dan $\mathrm{Fv}=1.90$. Spektrum respon desain ditentukan dengan menggunakan persamaan (7) dan persamaan (8) yang ada dalam SNI 03-1726-2019 pasal 6(3), didapat nilai percepatan respon periode pendek $(\mathrm{SDs})=0.733$ dan Percepatan respon periode 1 detik $(\mathrm{SD} 1)=$ 0.507 .

Periode fundamental struktur pendekatan ditentukan dalam pasal 7.8.2.1 SNI 03-1726-2019. Berdasarkan tabel parameter periode fundamental pendekatan (Ta) dengan rangka gedung beton bertulang sesuai nilai parameter perioda pendekatan yang terdapat pada halaman 56 SNI 03-1726-2019, diperoleh nilai waktu getar $\mathrm{Ta}=$ 0.565 detik. Gedung perkantoran dalam penelitian ini merupakan rangka beton bertulang pemikul momen, sesuai dengan pasal 7.2.2 SNI 03-1726-2019 diperoleh dari tabel faktor koefisien modifikasi respon $\mathrm{R}=5$. Maka diperoleh nilai koefisien respon seismik (pasal 7.8.1.1 SNI 03-1726-2019) $\mathrm{Cs}=0.147$. Berdasarkan hasil analisa dengan menggunakan data koefisien respon seismik (Cs) dan berat seismik efektif (W) sebagaimana telah ditetapkan dalam $\begin{array}{llll}\text { pasal } & \text { 7.7.2 } & \text { SNI } & \text { 03-1726-2012 }\end{array}$ menjelaskan bahwa $\mathrm{W}$ harus menyertakan seluruh beban mati dan beban lainnya, didapat besar geser dasar seismik (V) $3173.80 \mathrm{kN}$ dan gaya gempa lateral (Fx) pada masing-masing tingkat struktur harus dihitung dengan menggunakan persamaan yang telah ditetapkan dalam pasal 7.8.3 SNI 03-1726-2019, didapat besar beban gempa tiap lantai Fix beban gempa arah sumbu X berturut dari lantai (i) 1 - 4 adalah 53,529 $\mathrm{kN}, 107,058 \mathrm{kN}, 160,587 \mathrm{kN}$ dan $132,225 \mathrm{kN}$. Sedangkan besar beban gempa tiap lantai Fiy beban gempa arah sumbu Y berturut dari lantai 1 4 adalah $62,451 \mathrm{kN}, 124,901 \mathrm{kN}, 187,352 \mathrm{kN}$ dan $154,262 \mathrm{kN}$. 


\section{Deformasi Struktur}

Dari hasil running model pada aplikasi software SAP2000 v.16, dapat diketahui besar displacement yang terjadi pada saat struktur menerima beban lateral, yang ditinjau terhadap salah satu titik pada bagian struktur yang bersangkutan. Deformed shaped dan displacement yang terjadi pada empat model struktur yaitu Model I sepenuhnya menggunakan elemen frame, Model II merupakan struktur yang dimodel dengan mengikut sertakan dinding pengisi tanpa plesteran sebagai shell element, Model III merupakan struktur yang dimodel menggunakan dinding pengisi dengan perkuatan plesteran sebagai shell element, dan Model IV merupakan struktur yang dimodel menggunakan dinding pengisi dengan perkuatan plesteran dan kawat loket sebagai shell element ditampilkan pada Gambar 13 sampai dengan Gambar 16 untuk struktur dengan deformasi akibat beban gempa arah X. Gambar 17 sampai dengan gambar 20 untuk struktur dengan deformasi akibat beban gempa arah Y. Gambar 21 sampai dengan Gambar 24 untuk struktur dengan deformasi gempa arah $\mathrm{X}$ akibat kombinasi pembebanan (beban mati + beban hidup + beban gempa). Gambar 25 sampai dengan Gambar 28 untuk struktur dengan deformasi gempa arah $\mathrm{Y}$ akibat kombinasi pembebanan (beban mati + beban hidup + beban gempa)

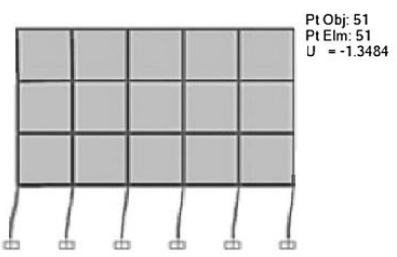

Gambar 13. Model I dengan Deformasi Akibat Gempa Arah X
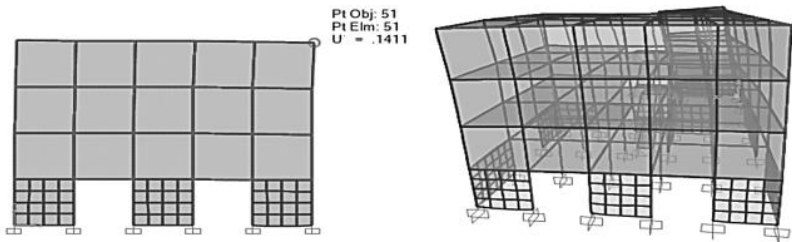

Gambar 14. Model II dengan Deformasi Akibat Gempa Arah X
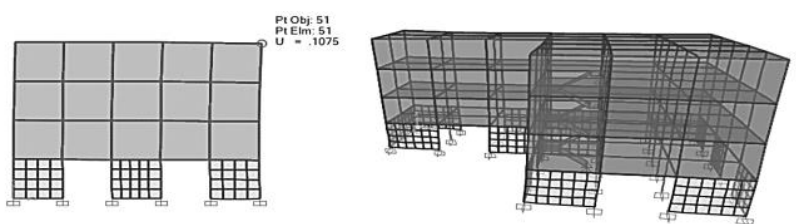

Gambar 15. Model III dengan Deformasi Akibat Gempa Arah X

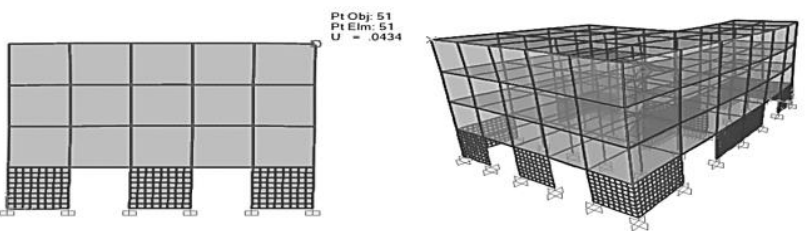

Gambar 16. Model IV dengan Deformasi Akibat Gempa Arah X
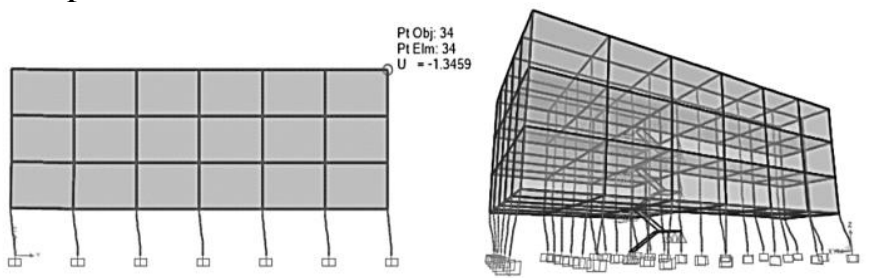

Gambar 17. Model I dengan Deformasi Akibat Beban Gempa Arah Y

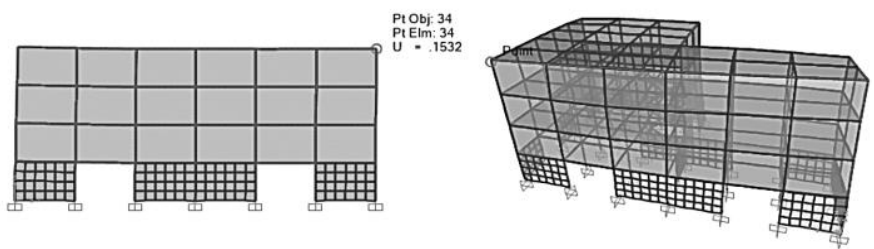

Gambar 18. Model II dengan Deformasi Akibat Beban Gempa Arah Y

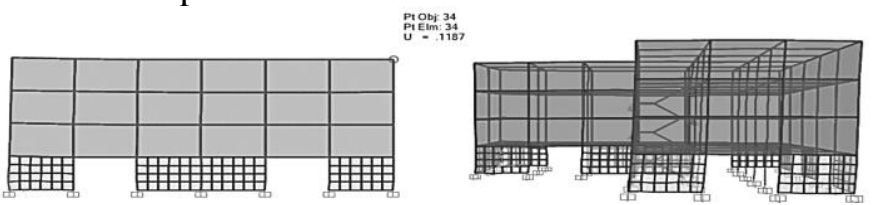

Gambar 19. Model III dengan Deformasi Akibat Beban Gempa Arah Y

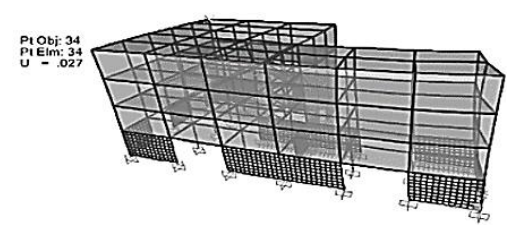

Gambar 20. Model IV dengan Deformasi Akibat Beban Gempa Arah Y
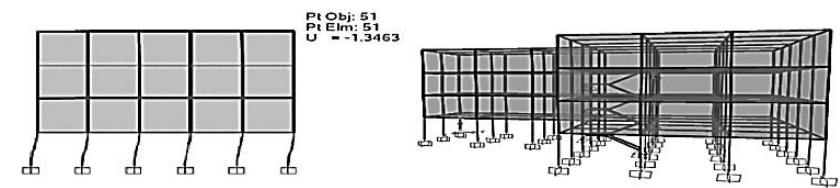

Gambar 21. Model I dengan Deformasi Gempa Arah X, Kombinasi Pembebanan (Beban Mati + Beban Hidup + Beban Gempa)

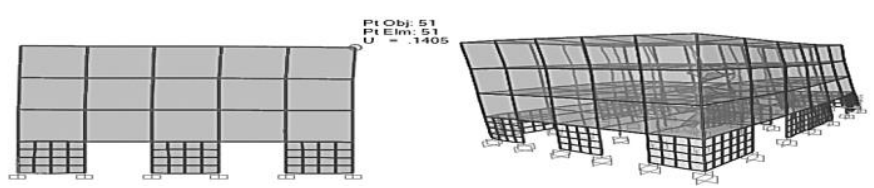

Gambar 22. Model II dengan Deformasi Gempa Arah X, Kombinasi Pembebanan (Beban Mati + Beban Hidup + Beban Gempa) 


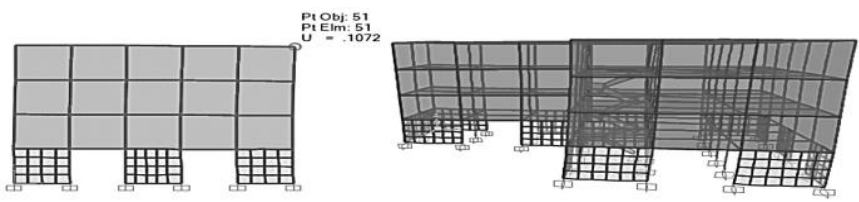

Gambar 23. Model III dengan Deformasi Gempa Arah X, Kombinasi Pembebanan

(Beban Mati + Beban Hidup + Beban Gempa)

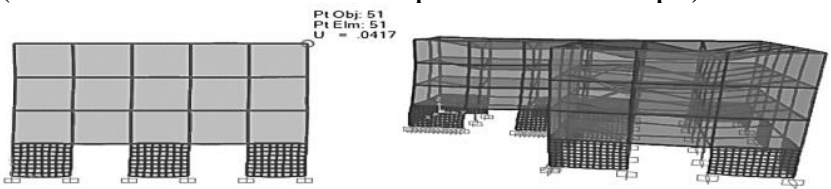

Gambar 24. Model IV dengan Deformasi Gempa Arah X, Kombinasi Pembebanan

(Beban Mati + Beban Hidup + Beban Gempa)
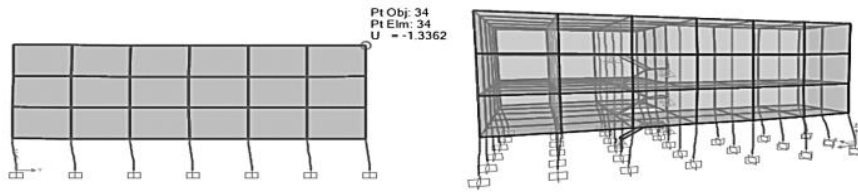

Gambar 25. Model I dengan Deformasi Gempa Arah Y, Kombinasi Pembebanan

(Beban Mati + Beban Hidup + Beban Gempa)

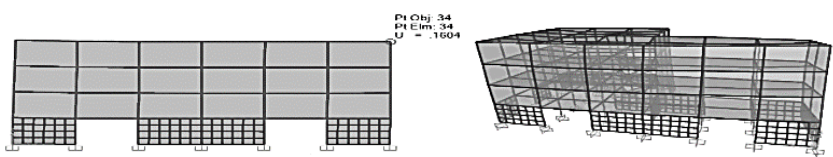

Gambar 26. Model II dengan Deformasi Gempa Arah Y, Kombinasi Pembebanan (Beban Mati + Beban Hidup + Beban Gempa)
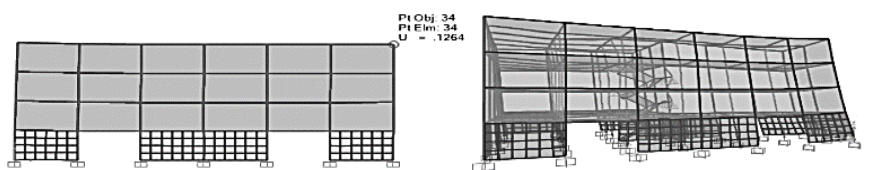

Gambar 27. Model III dengan Deformasi Gempa Arah Y, Kombinasi Pembebanan (Beban Mati + Beban Hidup + Beban Gempa)

Probi:

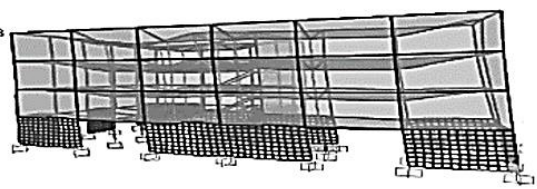

Gambar 28. Model IV dengan Deformasi Gempa Arah Y, Kombinasi Pembebanan (Beban Mati + Beban Hidup + Beban Gempa)

Dapat dilihat pada Model I, struktur mengalami deformasi yang cukup besar karena tidak dimodel dengan dinding pengisi pada lantai dasar yang dimana pada bagian lantai atas terdapat banyak dinding sebagai partisi karena digunakan sebagai ruang kerja (aktivitas perkantoran), sedangkan bagian bawah merupakan area parkir kendaran tanpa dinding pengisinya. Kondisi tersebut menyebabkan bagian atas relatif sangat kaku dibandingkan bagian bawah sehingga ketika terjadi gempa, struktur bagian bawah mengalami deformasi yang cukup besar dibandingkan deformasi pada lantai atas (Tabel 2 sampai dengan tabel 5).

Tabel 2. Deformasi Akibat Beban Gempa Arah X

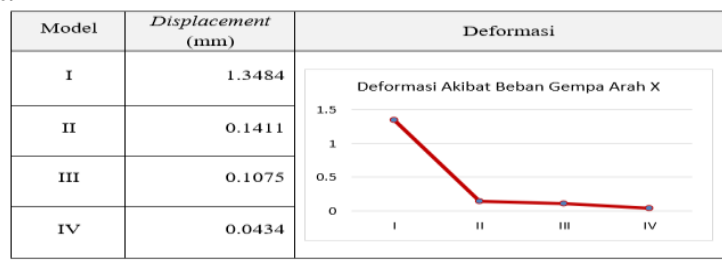

Tabel 3. Deformasi Akibat Beban Gempa Arah Y

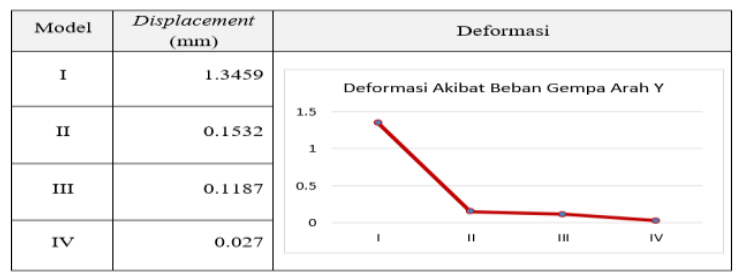

Tabel 4. Deformasi Gempa Arah X, Kombinasi Pembebanan

(Beban Mati + Beban Hidup + Beban Gempa)

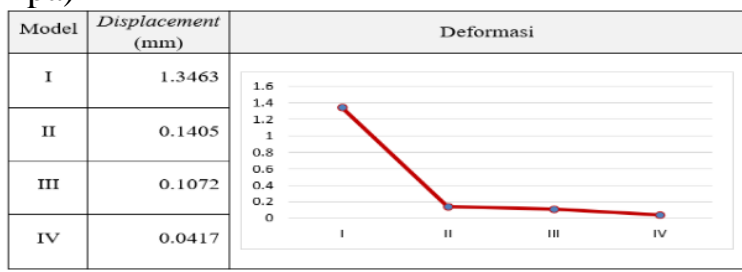

Tabel 5. Deformasi Gempa Arah Y, Kombinasi Pembebanan Gempa)

(Beban Mati + Beban Hidup + Beban

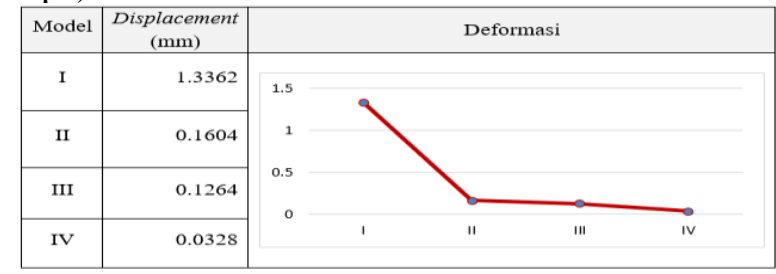

Berdasarkan hasil running model pada software SAP2000 v.16 perbandingan empat model struktur dapat dilihat bahwa displacement untuk rangka struktur dengan dinding pengisi (infilled 
frame) jauh lebih kecil dibandingkan dengan struktur rangka terbuka (open frame). Rangka struktur yang menggunakan dinding pengisi dengan dengan perkuatan plesteran dan kawat loket jauh lebih kaku jika dibandingkan dengan 3 (tiga) model lainnya apabila ditinjau terhadap beban gempa arah $\mathrm{X}$.

\section{Kekakuan Struktur}

Tingkat kekakuan dari 4 (empat) model struktur ditinjau terhadap beban gempa baik beban gempa arah X maupun beban gempa arah Y. Dari tabel 6 memperlihatkan bahwa rangka struktur dengan dinding pengisi (infilled frame) untuk Model II, $90 \%$ lebih kaku dibandingkan dengan struktur rangka terbuka (open frame) Model I; sedangkan Model III, $92 \%$ lebih kaku dibandingkan dengan Model I; dan Model IV, $97 \%$ lebih kaku dibandingkan dengan Model I yang jika ditinjau dari akibat beban gempa arah X. Jika ditinjau dari akibat beban gempa arah Y, rangka struktur dengan dinding pengisi (infilled frame) untuk Model II, $88 \%$ lebih kaku dibandingkan dengan struktur rangka terbuka (open frame) Model I; sedangkan Model III, $91 \%$ lebih kaku dibandingkan dengan Model I; dan Model IV, 99 \% lebih kaku dibandingkan dengan Model I.

Tabel 7. Prosentase Perbandingan Tingkat Kekakuan Struktur

\begin{tabular}{|c|c|c|c|c|}
\cline { 2 - 5 } \multicolumn{1}{c|}{} & Model I & Model II & Model III & Model IV \\
\hline Gempa Arah X & 1.3484 & 0.1411 & 0.1075 & 0.0434 \\
\hline $\begin{array}{c}\text { Prosentase } \\
\text { Perbandingan }\end{array}$ & - & $\begin{array}{c}90 \% \\
\text { lebih kaku }\end{array}$ & $\begin{array}{c}92 \% \\
\text { lebih kaku }\end{array}$ & $\begin{array}{c}97 \% \\
\text { lebih kaku }\end{array}$ \\
\hline Gempa Arah Y & 1.3459 & 0.1532 & 0.1187 & 0.027 \\
\hline $\begin{array}{c}\text { Prosentase } \\
\text { Perbandingan }\end{array}$ & - & $\begin{array}{c}88 \% \\
\text { lebih kaku }\end{array}$ & $\begin{array}{c}91 \% \\
\text { lebih kaku }\end{array}$ & $\begin{array}{c}99 \% \\
\text { lebih kaku }\end{array}$ \\
\hline
\end{tabular}

\section{Gaya-Gaya Dalam pada Struktur}

Selain membandingkan besar displacement dari 4 (empat) model struktur, dalam penelitian ini juga membandingkan besar momen (Gambar 29), gaya lintang (Gambar 30) yang terjadi ditinjau terhadap salah satu object/elemen dan perbandingan tegangan yang terjadi pada dinding pengisi (Tabel 8).

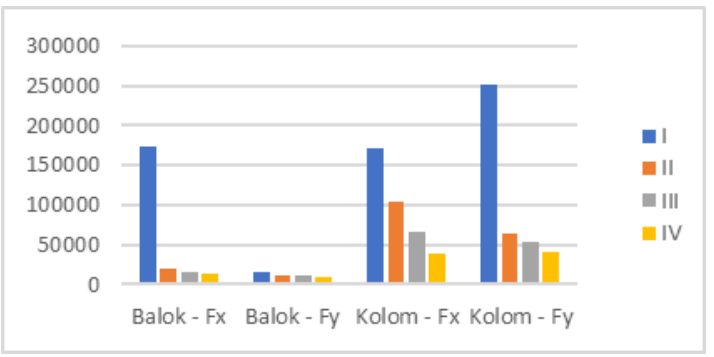

Gambar 29. Grafik Besar Momen yang Terjadi $(\mathrm{KNm})$ pada Balok dan Kolom

Gambar 29 dan Gambar 30, momen rangka struktur dengan dinding pengisi lebih kecil dibandingkan dengan struktur rangka terbuka (open frame), dan demikian pula dengan besar gaya lintang yang terjadi pada rangka struktur dengan dinding pengisi (Model II, Model III, Model IV) lebih kecil dibandingkan dengan struktur rangka terbuka (Model I) baik ditinjau akibat beban gempa arah $\mathrm{X}$ maupun akibat beban gempa arah Y.

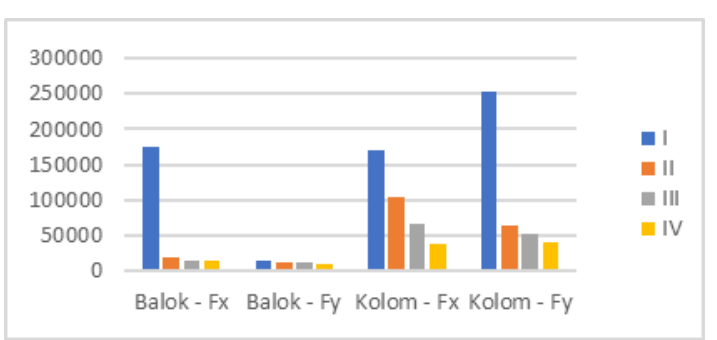

Gambar 30. Grafik Besar Momen yang Terjadi (KNm) pada Balok dan Kolom

Tabel 8. Tegangan pada Dinding Pengisi Akibat Gempa Arah X dan Arah Y

\begin{tabular}{|c|c|c|c|c|c|c|}
\hline Model & Nilai $\left(\mathbf{K N} / \mathbf{m}^{2}\right)$ & \multicolumn{5}{|c|}{ Deformasi } \\
\hline II & 1177166.7 & \multicolumn{5}{|c|}{$\begin{array}{l}\text { Deformasi Akibat Beban Gempa } \\
\text { Arah X }\end{array}$} \\
\hline III & 1126063.8 & \multirow{3}{*}{$\begin{array}{r}1200000 \\
1100000 \\
1000000 \\
900000 \\
0\end{array}$} & & \multicolumn{3}{|c|}{0} \\
\hline & & & & & 0 & \\
\hline IV & 986852.3 & & 1 & 2 & 3 & 4 \\
\hline Model & Nilai $\left(\mathrm{KN} / \mathrm{m}^{2}\right)$ & \multicolumn{5}{|c|}{ Deformasi } \\
\hline II & 2755011.6 & \multicolumn{5}{|c|}{$\begin{array}{l}\text { Deformasi Akibat Beban Gempa } \\
\text { Arah Y }\end{array}$} \\
\hline III & 2450358.5 & \multirow{2}{*}{$\begin{array}{r}3000000 \\
2000000 \\
1000000 \\
0\end{array}$} & 0 & 0 & & \\
\hline IV & 1328136.7 & & 1 & 2 & 3 & 4 \\
\hline
\end{tabular}

Dari tabel 8, tegangan yang terjadi pada dinding pengisi Model II lebih besar dibandingkan dengan Model IV dan Model III jika ditinjau akibat beban gempa arah $\mathrm{X}$ maupun ditinjau akibat beban 
gempa arah Y. Berdasarkan hasil analisa tersebut di atas, dari segi keamanan dan tingkat kekakuan, struktur gedung bertingkat yang menggunakan dinding pengisi (infilled frame) jauh lebih aman dan lebih kaku dibandingkan dengan struktur rangka terbuka (open frame) dan sangat memenuhi syarat untuk digunakan pada daerah yang beresiko gempa tinggi. Area parkir kendaraan dengan tipe open frame sebaiknya dihindari, dan dalam pelaksanaan pekerjaan konstruksi ada baiknya tetap memperhitungkan pentingnya keberadaan dinding pengisi guna menghindari terjadinya keruntuhan softstory.

\section{KESIMPULAN}

Analisa tentang kekakuan struktur dengan adanya dinding pengisi telah dilakukan melalui kajian pustaka dan running model pada program SAP2000 V.16, dengan 4 (empat) model yaitu: Model I sepenuhnya menggunakan elemen frame, Model II merupakan struktur yang dimodel dengan mengikut sertakan dinding pengisi tanpa plesteran sebagai shell element, Model III merupakan struktur yang dimodel menggunakan dinding pengisi dengan perkuatan plesteran sebagai shell element, dan Model IV merupakan struktur yang dimodel menggunakan dinding pengisi dengan perkuatan plesteran dan kawat loket sebagai shell element. Dari hasil analisa, dapat diambil kesimpulan sebagai berikut:

Model II, $90 \%$ lebih kaku dibandingkan dengan struktur rangka terbuka (open frame) Model I; sedangkan Model III, 92 \% lebih kaku dibandingkan dengan Model I; dan Model IV, $97 \%$ lebih kaku dibandingkan dengan Model I yang jika ditinjau dari akibat beban gempa arah X. Jika ditinjau dari akibat beban gempa arah Y, rangka struktur dengan dinding pengisi (infilled frame) untuk Model II, $88 \%$ lebih kaku dibandingkan dengan struktur rangka terbuka Model I; sedangkan Model III, $91 \%$ lebih kaku dibandingkan dengan Model I; dan Model IV, $99 \%$ lebih kaku dibandingkan dengan Model I.

Nilai momen dan gaya lintang Model II, Model III, Model IV lebih kecil dibandingkan dengan Model I baik ditinjau akibat beban gempa arah $\mathrm{X}$ maupun akibat beban gempa arah $\mathrm{Y}$. Tegangan yang terjadi pada dinding pengisi Model II lebih besar dibandingkan dengan Model IV dan
Model III jika ditinjau akibat beban gempa arah X maupun ditinjau akibat beban gempa arah Y.

Dari segi keamanan, struktur gedung bertingkat yang menggunakan dinding pengisi jauh lebih aman dan lebih kaku dibandingkan dengan struktur rangka terbuka dan sangat memenuhi syarat untuk digunakan pada daerah yang beresiko gempa tinggi.

\section{DAFTAR PUSTAKA}

Anonim, (2007), Analysis Reference Manual SAP 2000, Computer and Structures, Inc. California, USA.

Badan Standardisasi Nasional, SNI 07-0663-1995. (1995). Jaring Kawat Baja Las Untuk Tulangan Beton, Bandung.

Badan Standardisasi Nasional, SNI 15-0686-1989. (1989). Bata Merah Karawang, Bandung.

Badan Standardisasi Nasional, SNI 03-1726-2019. (2019). Tata Cara Perencanaan Ketahanan Gempa Untuk Struktur Bangunan Gedung dan Non Gedung, Bandung.

Badan Standardisasi Nasional, SNI 15-2049-2004. (2004). Semen Portland, Bandung.

Badan Standardisasi Nasional, SNI 03-2847-2019. (2019). Tata Cara Perhitungan Struktur Beton Untuk Bangunan Gedung, Bandung.

British Standard Institution, BS 5628-1-1992: Code of Practice for Use of Masonry, Part 1: Structural Use of Unreinforced Masonry, London.

Fianli, C. (2011). Dinding Bangunan. Universitas Diponegoro. Bandung.

Hutchison, R. (1995). Building Knocked off its Foundation by the January 1995 Earthquake in Kōbe, Japan. National Geophysical Data Center.

IIEES. (2016). Kobe Earthquake of 17 January 2015, Mw 6.9. International Institute of Earthquake Engineering and Seismology

Sukrawa, M., (2020), Sumbangan Dinding Pengisi terhadap Ketahanan Struktur Menahan Beban Gempa, Orasi Ilmiah Guru Besar Universitas Udayana. 